OPEN ACCESS

Edited by:

Wei Jiang,

Guangxi University, China

Reviewed by:

Susana Enríquez,

National Autonomous University

of Mexico, Mexico

Douglas Fenner,

Independent Researcher, Pago Pago,

American Samoa

Nicole D. Fogarty,

University of North Carolina

at Wilmington, United States

*Correspondence:

Johanna Calle-Triviño

johanna.calle@iberostar.com

Jesús Ernesto Arias-González

earias@cinvestav.mx

Specialty section:

This article was submitted to

Coral Reef Research,

a section of the journal

Frontiers in Marine Science

Received: 16 February 2021 Accepted: 07 June 2021

Published: 25 June 2021

Citation:

Calle-Triviño J, Muñiz-Castillo Al,

Cortés-Useche C, Morikawa M,

Sellares-Blasco $R$ and

Arias-González JE (2021) Approach

to the Functional Importance

of Acropora cervicornis in Outplanting

Sites in the Dominican Republic.

Front. Mar. Sci. 8:668325.

doi: 10.3389/fmars.2021.668325

\section{Approach to the Functional Importance of Acropora cervicornis in Outplanting Sites in the Dominican Republic}

\author{
Johanna Calle-Triviño ${ }^{1,2 *}$, Aarón Israel Muñiz-Castillo1, Camilo Cortés-Useche ${ }^{1,2}$, \\ Megan Morikawa ${ }^{3}$, Rita Sellares-Blasco ${ }^{4}$ and Jesús Ernesto Arias-González ${ }^{1 *}$
}

'Department of Marine Resources, Center for Research and Advanced Studies, National Polytechnic Institute of Mexico, Mérida, Mexico, ${ }^{2}$ Wave of Change, Iberostar Hotels and Resorts, Quintana Roo, Mexico, ${ }^{3}$ Wave of Change, Iberostar Hotels and Resorts, Miami, FL, United States, ${ }^{4}$ Dominican Foundation for Marine Studies, Bayahibe, Dominican Republic

Coral restoration has been recognized as an increasingly important tool for coral conservation in recent years. In the Caribbean, the endangered staghorn coral, Acropora cervicornis has been studied for restoration for over two decades with most studies focusing on evaluating simple metrics of success such as colony growth and survivorship in both nurseries and outplanted sites. However, for reef restoration to aid in the recovery of ecological function in outplanted sites, there is a need to measure the functional ecology of the impact of outplanting. Here, we present and identify positive ecological processes and ecological functions (such as increased fish biomass, coral cover, and increased in structural complexity) relative to active reef restoration. In the Southeastern Reefs Marine Sanctuary in the Dominican Republic, we monitored the percentage of benthic cover and fish biomass alongside active reef restoration over the period of 12 months in four zones. Subsequently, we developed multidimensional analyses in conjunction with generalized linear models (GLM) and linear models. Our results show there is a remarkable spatial and temporal differentiation favoring greater ecological function in restored areas. We observed the most noticeable patterns of change in the benthos and coral species composition. We found a positive relationship between amounts of outplanted colonies with the total fish biomass for the three outplanted sites. We highlight that Scarus iseri, a parrotfish critical for grazing maintenance, was the species with the greatest benefit. Our results provide evidence of the functional importance of Acropora cervicornis in coral reef active restoration efforts.

Keywords: Acropora cervicornis, coral reef restoration, outplanting sites, ecosystem services, Dominican Republic

\section{INTRODUCTION}

For decades, coral reefs have undergone a series of changes in structure and function due to a wide range of environmental and anthropogenic impacts (D'agata et al., 2014; Anthony et al., 2015; Pendleton et al., 2016; Hughes et al., 2017). Therefore, one of the challenges for researchers, authorities and local communities is to achieve the restoration of these ecosystems and their 
services (Hughes et al., 2018; Lamb et al., 2018). Over the past 20 years, active reef restoration through human intervention has increased worldwide to mitigate the decline in coral cover. Propagation of corals for restoration is now considered an essential component of coral reef conservation and management strategies (Rinkevich, 2005, 2015; Precht, 2006; Edwards and Gómez, 2007; Petersen et al., 2007; Edwards, 2010; Johnson et al., 2011; Nakamura et al., 2011; Toh et al., 2012; Young et al., 2012; Chamberland et al., 2015; Lirman and Schopmeyer, 2016; Schopmeyer et al., 2017; Calle-Triviño et al., 2018, 2020; Bayraktarov et al., 2020; Shaver et al., 2020).

In the Caribbean, in the 1980s, there was a loss of up to $97 \%$ cover of Acropora cervicornis and Acropora palmata (Gladfelter, 1982; Porter et al., 1982; Knowlton, 1992; Miller et al., 2002), this decline caused its inclusion in the Union for Conservation of Nature (IUCN) as critically endangered species, and in Appendix II of the Convention on International Trade in Endangered Species of Wild Fauna and Flora (CITES) (Aronson et al., 2008). It decreases also has resulted in losses in the three-dimensional structure of shallow reefs and in ecological, economic, and social services (Bruckner, 2002; Vargas-Ángel et al., 2006; Alvarez-Filip et al., 2009).

A. cervicornis has had limited recovery due to the interactions and positive feedback of natural and anthropogenic stresses that exist at both local and global levels (Precht et al., 2002; Weil et al., 2002; Carpenter et al., 2008; Agudo-Adriani et al., 2016). To promote coral cover recovery, restoration programs in the Caribbean region have intensified the propagation of A. cervicornis fragments (Bowden-Kerby, 2001; HernándezDelgado et al., 2001; Young et al., 2012; Lirman et al., 2014). While restoration efforts have increased exponentially (Lirman and Schopmeyer, 2016), few studies have been published on the recovery of ecosystem functions and services in outplanting sites (Griffin et al., 2012; Lirman et al., 2014; Schopmeyer et al., 2017; Calle-Triviño et al., 2020). The branching morphology of A. cervicornis provides important structural complexity for different reef organisms. Complex interactions and energy flows are formed around this species, such as high levels of primary productivity and associations between different species (Itzkowitz, 1978; Lirman, 1999; Bruckner, 2002; Goergen et al., 2019). Because of its life history characteristics and its high growth rate it has been one of the species selected to develop restoration projects in the Caribbean (Young et al., 2012; Calle-Triviño et al., 2018). However, no published scientific studies address functional aspects of $A$. cervicornis in outplanted areas, and a deeper understanding of the role this species plays in creating and modifying reef fish habitats is needed (Huntington et al., 2017).

Generally, the "success" of restoration programs in the Caribbean region has been measured a single variable (i.e., growth, survival, annual productivity or percentage coverage) (Lirman and Schopmeyer, 2016; Schopmeyer et al., 2017; Ladd et al., 2018, 2019; Calle-Triviño et al., 2020; Seraphim et al., 2020). This single-variable approach at the organism level does not allow for the identification of successional processes that occur in outplanted areas and the effects on functions and resilience in these areas are unknown. The scale of the analysis to the ecosystem level to describe correlations among groups can be useful tool to evaluate restoration programs, on the premise that $A$. cervicornis performs as an indirect facilitating agent, providing three-dimensionality across habitat, increasing refuge availability, niches, food availability and regulating interactions between organisms on coral reefs (Graham and Nash, 2013; Agudo-Adriani et al., 2016; Floros and Schleyer, 2017).

In 2011, the Dominican Foundation for Marine Studies (FUNDEMAR) began its coral restoration program with the purpose of using fragments of the A. cervicornis coral to attempt to repopulate degraded reef areas in Bayahibe on the southeastern end of the island (Calle-Triviño et al., 2020).

In 2015, three outplanted sites and one control site were monitored for twelve consecutive months to identify if there was an influence on benthic composition, abundance of coral and fish species in the outplanted sites over time, and the interaction between these variables. In this study, we analyzed changes in benthos and in fish communities due to restoration actions in outplanted sites in the Southeaster Reefs Marine Sanctuary in the Dominican Republic.

\section{MATERIALS AND METHODS}

\section{Study Location}

The outplanted sites studied are part of the Southeast Reefs Marine Sanctuary (Figure 1). The sanctuary includes a chain of coral reefs located along the southeastern coast of the Dominican Republic with a total area of $7,862.59 \mathrm{~km}^{2}$. It was declared a protected area on August 7, 2009 by Decree No. 571-09. The reefs within the sanctuary and adjacent areas are an important tourist attraction. The study was carried out in three outplanted sites ZT1, ZT2, ZT3, and a control site "Peñon" (Table 1) all included in the area of the municipality of Bayahíbe.

\section{Outplant and Control Site Establishment}

During the selection and establishment of the outplanting and control sites, prospective dives were carried out in order to ensure that the selection criteria were achieved. Criteria for selection of outplanting sites included: depth (between 12 and $15 \mathrm{~m}$ ), presence of wild A. cervicornis colonies, low sedimentation, low macroalgae cover, and the presence of calcareous coralline algae (CCA) (Edwards, 2010; Johnson et al., 2011; MercadoMolina et al., 2013; Arias-González et al., 2015; Carne et al., 2016). Before outplanting, the substrate was cleaned using different hand tools (brushes, chisels, hammers) to remove algal mats, sediments, or macroalgae, but the CCA was undisturbed (Calle-Triviño et al., 2020).

After properly preparing the substrate, squared galvanized masonry steel nails were placed in the substrate, keeping a distance of $0.5-1 \mathrm{~m}$ between the nails (Mercado-Molina et al., 2013) obtaining outplant densities of 1.5 colonies per square meter. All of the outplanted colonies were harvested from FUNDEMAR's main nursery. At that time, the genotype of the fragments was not taken into account, since the nursery had not yet been genotyped. However, it is currently known the nursery supports at least 32 individuals, indicating there was 


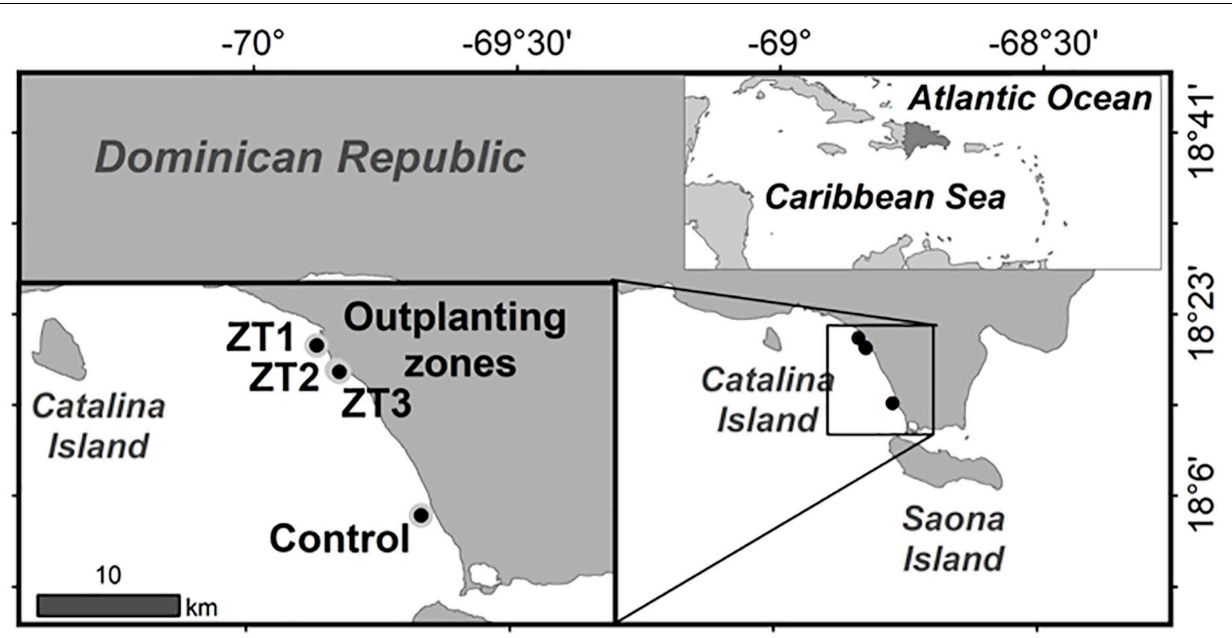

FIGURE 1 | Map of outplanted sites and control site part of the Arrecifes del Sureste Marine Sanctuary

likely a mixture of genets that contributed to the outplanting. All the outplanted colonies had a size $>45 \mathrm{~cm}$ of linear growth, and fixed to the pre-established nails with plastic cable ties (Johnson et al., 2011). All the selection criteria and the techniques used to perform the transplants are described in Calle-Triviño et al. (2020). In each of the outplanting sites, a total of 200 colonies were outplanted in an area of $200 \mathrm{~m}^{2}$, at a depth between 12 and $15 \mathrm{~m}$.

The control area (Peñon) was chosen taking into account different selection criteria, including depth (which was similar to the outplanting areas, between 12 and $15 \mathrm{~m}$ ), distance from outplant sites $(<500 \mathrm{~m})$, and available historical information (Cortés-Useche et al., 2019). A single control site was chosen due to logistical and budgetary limitations of the project.

\section{Sampling Design}

In each of the three outplanted sites and in the control site, six transects of $10 \mathrm{~m}$ each were randomly selected based on the AGRRA (Atlantic and Gulf Reef Rapid Reef Assessment) Version 5.4 protocol (Lang et al., 2010). These transects were subsequently installed permanently along the sites to carry out the assessments. Four monitoring cycles were conducted during a 12-month period. The point intercept methodology was used for the benthos information survey, with measurements collected every $10 \mathrm{~cm}$ in each of the six $10 \mathrm{~m}$ transects; the

TABLE 1 | Codes and Geographical coordinate of the outplanted sites and control site in Bayahíbe, Dominican Republic.

\begin{tabular}{lcc}
\hline & Geographic coordinate \\
\hline Codes & N & E \\
\hline ZT1 & $18.3609^{\circ}$ & $-68.84515^{\circ}$ \\
ZT2 & $18.34533^{\circ}$ & $-68.83232^{\circ}$ \\
ZT3 & $18.34424^{\circ}$ & $-68.83087^{\circ}$ \\
Control & $18.253^{\circ}$ & $-68.779^{\circ}$
\end{tabular}

category corresponding to the substrate observed just below each point was recorded. To determine the abundances of fish in each of the outplanted areas and the control area, four temporary belt transect surveys were performed $(30 \mathrm{~m}$ long $\times 2 \mathrm{~m}$ wide) in the same habitat as the permanent transects. In each belt transect, the number of individuals corresponding to the commercially and/or ecologically important reef fish species covered by the AGRRA protocol was recorded, as well as their sizes in the proposed class size ranges in the protocol. Using the abundance and size class data, biomass was calculated using the length-weight relationship equation $W=\mathrm{aLb}$ described by Bonsack and Harper (1988). Constants (a and b) for length-weight relationships for each species were obtained from Froese and Pauly (2019).

In addition, we used the methodology proposed by Schopmeyer et al. (2017) to evaluate the growth, survival, and productivity of the colonies transplanted in outplanting sites. Schopmeyer et al. (2017) proposed the following reference points for measuring the first year of A. cervicornis restoration: (1) the survival of outplanted corals must be greater than $70 \%$ and (2) average productivity should be $>4.8 \mathrm{~cm} \mathrm{year}^{-1}$ for outplanted corals.

We monitored sites every 3 months during the 12-month period after their establishment. Colonies from outplanted sites were individually labeled. Growth was expressed as Total Linear Extension (TLE) in $\mathrm{cm}$ over time for each coral, measuring from base to tip of each branch and adding up all the branches to obtain total growth of each colony (Johnson et al., 2011; Lirman et al., 2014). Data on growth, survival, and annual productivity were taken as presented by Calle-Triviño et al. (2020), and proposed and used by Lirman et al. (2014) and Schopmeyer et al. (2017) as follows:

- Total annual growth $=($ Final Measure - Initial Measure $)$.

- $\%$ Survival $=(\#$ final live colonies $\times 100) / \#$ initial live colonies.

- Annual productivity = (growth/initial TLE). 
The mean annual productivity was calculated by pooling all outplants. This measure was proposed by Lirman et al. (2014) and used by Schopmeyer et al. (2017). We have used the same measure in order to compare results in this publication with similar studies in the United States and Puerto Rico.

\section{Benthos Analysis and Coral Species Composition}

Generalized linear model (GLM) analysis was applied to identify changes in composition of benthos, coral, and fish species in the outplanting sites over time. This analysis considers variations in abundance values and allows us to consider different types of error distributions (Warton et al., 2015). For the GLMs the negative binomial distribution was used with a link function of logarithm, because it showed the best results, reducing the over-dispersion present in the data. For hypothesis testing, 999 permutations were applied using Monte Carlo simulations, and considered within the univariate analysis influence (significance of each species) for which an adjustment procedure based on multiple tests from step-by-step resampling was used. This analysis was performed using the "mvabund" library of the statistical program R (Warton et al., 2012; R Development Core Team, 2015).

In order to know the fit and confirm the model assumptions were not violated, analysis graphs were obtained for model residuals. In other work conducted on coral reefs, biomass has been properly modeled from negative binomial GLM, thus capturing over-dispersion present in the biomass data (Ferrari et al., 2018). The ordination was visualized from a non-metric multidimensional scaling, based on the Bray-Curtis dissimilarity matrices, using data transformed to the logarithm. This analysis was made from program R's "vegan" library. These analyses were conducted for all data transects within each site and on each of the dates sampled.

\section{Measuring Ecological Indicators Associated With Outplanting Efforts}

To determine the increase in some variables, considered as a positive effect due to outplanting actions, two main variables known as coral indicators were calculated and obtained: (1) coral cover and (2) coefficient of functionality. Moreover, the total fish biomass and biomass of species showed a significant temporal change in the analysis of GLM.

Coral coverage was obtained directly from the benthos percentage coverage data. The coefficient of functionality was calculated considering the values and equation presented in the work of González-Barrios and Álvarez-Filip (2018). This is derived from the Reef Functional Index (RFI) which is a sitelevel indicator. The coefficient within the RFI quantifies the structural complexity of coral based on parametric models of coral growth and complexity of morphology (González-Barrios and Álvarez-Filip, 2018). We decided to explore the use of combined descriptors such as the RFI, as an additional descriptor to the analysis that may be relevant in reef research, provided that the robustness of this index is demonstrated in future work.
TABLE 2 | Coral and fish species observed in the three outplanting sites and control sites.

\begin{tabular}{|c|c|c|c|c|}
\hline Coral species & ZT1 & ZT2 & ZT3 & CONTROL \\
\hline Acropora cervicornis & $x$ & $x$ & $x$ & $x$ \\
\hline Agaricia spp. & $x$ & $x$ & $x$ & $x$ \\
\hline Colpophyllia natans & $x$ & $x$ & $x$ & $x$ \\
\hline Dendrogyra cylindrus & $x$ & $x$ & & \\
\hline Dichocoenia stokesii & & & & $x$ \\
\hline Diploria labyrinthiformis & $x$ & $X$ & $X$ & $x$ \\
\hline Eusmillia fastigiata & $x$ & & & $x$ \\
\hline Favia fragum & & & $x$ & \\
\hline Isophyllia sinuosa & $x$ & & & \\
\hline Madracis spp. & $x$ & $x$ & $X$ & $x$ \\
\hline Meandrina meandrites & $x$ & $x$ & $x$ & $x$ \\
\hline Millepora alcicornis & $x$ & $x$ & $x$ & $x$ \\
\hline Montastraea cavernosa & $x$ & $x$ & $x$ & $x$ \\
\hline Mussa angulosa & & & & $x$ \\
\hline Mycetophyllia spp. & & $X$ & $x$ & $x$ \\
\hline Orbicella annularis & $x$ & $x$ & $x$ & \\
\hline Orbicella faveolata & $x$ & $x$ & $x$ & $x$ \\
\hline Orbicella franksii & $x$ & $x$ & $x$ & $x$ \\
\hline Porites astreoides & $x$ & $x$ & $x$ & $x$ \\
\hline Porites divaricata & $x$ & & & $x$ \\
\hline Porites furcata & $x$ & & & $x$ \\
\hline Porites porites & $x$ & $x$ & $x$ & $x$ \\
\hline Pseudodiploria clivosa & $x$ & & & $x$ \\
\hline Pseudodiploria strigosa & $x$ & $x$ & $x$ & $x$ \\
\hline Scolymia spp. & & & & $x$ \\
\hline Siderastrea radians & & & & $x$ \\
\hline Siderastrea siderea & $x$ & $x$ & & $x$ \\
\hline Solenastrea bournoni & $x$ & $x$ & & $x$ \\
\hline Stephanocoenia intersepta & $x$ & & & $x$ \\
\hline
\end{tabular}

\begin{tabular}{lllll}
\hline Fish species & ZT1 & ZT2 & ZT3 & CONTROL
\end{tabular}

Acanthurus bahianus

Acanthurus chirurgus

Acanthurus coeruleus

Aluterus scriptus

Balistes vetula

Bodianus rufus

Cantherhines macroceros

Cantherhines pullus

Caranx ruber

Chaetodon aculeatus

Chaetodon capistratus

Chaetodon ocellatus

Diodon hystrix

Epinephelus cruentatus

Epinephelus fulvus

Haemulon aurolineatum

Haemulon carbonarium

Haemulon chrysargyreum

Haemulon flavolineatum

Haemulon plumieri

Haemulon sciurus

Halichoeres garnoti

\begin{tabular}{|c|c|c|c|}
\hline$x$ & $x$ & $X$ & $x$ \\
\hline$x$ & $x$ & $x$ & $x$ \\
\hline$X$ & $x$ & $x$ & $x$ \\
\hline$x$ & $x$ & $x$ & $x$ \\
\hline$x$ & $x$ & $x$ & $X$ \\
\hline$x$ & $x$ & $X$ & $x$ \\
\hline$X$ & $x$ & $x$ & $x$ \\
\hline$x$ & $x$ & $x$ & $X$ \\
\hline$x$ & $x$ & $x$ & $x$ \\
\hline$x$ & $x$ & $x$ & $x$ \\
\hline$x$ & $x$ & $x$ & $X$ \\
\hline$x$ & $x$ & $x$ & $X$ \\
\hline$X$ & $x$ & $x$ & $x$ \\
\hline$X$ & $X$ & $x$ & $X$ \\
\hline$X$ & $x$ & $x$ & $X$ \\
\hline$x$ & $x$ & $X$ & $x$ \\
\hline$x$ & $x$ & $x$ & $X$ \\
\hline$x$ & $x$ & $x$ & $x$ \\
\hline$x$ & $x$ & $x$ & $x$ \\
\hline$x$ & $x$ & $x$ & $x$ \\
\hline$x$ & $x$ & $X$ & $x$ \\
\hline$X$ & $x$ & $x$ & $X$ \\
\hline
\end{tabular}

(Continued) 
TABLE 2 | Continued

\begin{tabular}{lcccc}
\hline Coral species & ZT1 & ZT2 & ZT3 & CONTROL \\
\hline Holacanthus tricolor & $\mathrm{X}$ & $\mathrm{X}$ & $\mathrm{X}$ & $\mathrm{X}$ \\
Lactophrys bicaudalis & $\mathrm{X}$ & $\mathrm{X}$ & $\mathrm{X}$ & $\mathrm{X}$ \\
Lutjanus analis & $\mathrm{X}$ & $\mathrm{X}$ & $\mathrm{X}$ & $\mathrm{X}$ \\
Lutjanus apodus & $\mathrm{X}$ & $\mathrm{X}$ & $\mathrm{X}$ & $\mathrm{X}$ \\
Lutjanus mahogoni & $\mathrm{X}$ & $\mathrm{X}$ & $\mathrm{X}$ & $\mathrm{X}$ \\
Lutjanus synagris & $\mathrm{X}$ & $\mathrm{X}$ & $\mathrm{X}$ & $\mathrm{X}$ \\
Melichthys niger & $\mathrm{X}$ & $\mathrm{X}$ & $\mathrm{X}$ & $\mathrm{X}$ \\
Microspathodon chrysurus & $\mathrm{X}$ & $\mathrm{X}$ & $\mathrm{X}$ & $\mathrm{X}$ \\
Ocyurus chrysurus & $\mathrm{X}$ & $\mathrm{X}$ & $\mathrm{X}$ & $\mathrm{X}$ \\
Pomacanthus paru & $\mathrm{X}$ & $\mathrm{X}$ & $\mathrm{X}$ & $\mathrm{X}$ \\
Pterois spp. & $\mathrm{X}$ & $\mathrm{X}$ & $\mathrm{X}$ & $\mathrm{X}$ \\
Scarus iseri & $\mathrm{X}$ & $\mathrm{X}$ & $\mathrm{X}$ & $\mathrm{X}$ \\
Scarus taeniopterus & $\mathrm{X}$ & $\mathrm{X}$ & $\mathrm{X}$ & $\mathrm{X}$ \\
Scarus vetula & $\mathrm{X}$ & $\mathrm{X}$ & $\mathrm{X}$ & $\mathrm{X}$ \\
Sparisoma atomarium & $\mathrm{X}$ & $\mathrm{X}$ & $\mathrm{X}$ & $\mathrm{X}$ \\
Sparisoma aurofrenatum & $\mathrm{X}$ & $\mathrm{X}$ & $\mathrm{X}$ & $\mathrm{X}$ \\
Sparisoma chrysopterum & $\mathrm{X}$ & $\mathrm{X}$ & $\mathrm{X}$ & $\mathrm{X}$ \\
Sparisoma viride & $\mathrm{X}$ & $\mathrm{X}$ & $\mathrm{X}$ & $\mathrm{X}$ \\
Sphoeroides spengleri & $\mathrm{X}$ & $\mathrm{X}$ & $\mathrm{X}$ \\
\hline & & & & \\
\hline
\end{tabular}

Regression models were performed to explain changes in cover, RFI, Total fish biomass and Scarus iseri biomass as a function of time (as an indicator of effort from outplanting actions), as well as models explaining changes in total fish biomass and significant fish species in the multi-dimensional GLM as a function of coral cover percentage and change in RFI (as a measure of structural complexity and proxy indicator of coral cover). Linear regression models, based on median data for sampling site and date, were chosen for this analysis using the untransformed data for coral cover and RFI, as well as a $\log$ transformation for fish biomass. Graphical residual assessments and a global test of linear models were carried out to verify the regression models' assumptions (Pena and Slate, 2006). Regression curves of the prediction lines and 95\% Wald confidence bands were plotted using the "visreg" package of the R program (Breheny and Burchett, 2017).

\section{Hurricane Season 2016 and 2017}

The impact of Hurricanes Mathew (2016), Irma and Maria (2017) could only be quantified for benthos in ZT1, due to the climatic and logistical conditions occurring in the area just after those events.

To recognize differences in coral cover and RFI, as well as total fish biomass during the period of the hurricanes (September 2016 and September 2017), a strong statistical paired sample test was conducted. In comparison, the values for the indicators mentioned above were used at the site level, considering as dependent samples each of the transects carried out during September 2016 and February 2017. There was no homogeneity of variances or normality, so we chose to perform a Yuend test for difference in trimmed means, considering only values found within the 10th and 80th percentiles of the data distribution. For the test, a 95\% confidence level was considered, based on the WRS2 library of the R statistical program (Mair et al., 2016).

\section{RESULTS}

In the three outplanting and control sites, 29 species of coral and 41 species of fishes were observed (Table 2 ). The Scaridae family presented highest abundances, followed by the Acanthuridae family. During the 12 months of study, changes in benthic coverage (Supplementary Table 1), relative coverage of coral species (Supplementary Table 2), and relative biomass of fish species (Supplementary Table 3) were observed across sites, dates, and site-date interactions.

\section{Growth, Survival and Annual Productivity}

Mean survival of A. cervicornis fragments for the three outplanted sites during the 12-month period was $67.16 \pm 13.8 \%$, with a range of $57-83 \%$. During this period, the most common cause of mortality was sedimentation and predation by the fireworm, Hermodice carunculata (Calle-Triviño et al., 2017, 2020). The three outplanted sites' mean productivity value was $3.53 \pm 1.40 \mathrm{~cm} \mathrm{year}^{-1}$ (Table 3 ).

\section{Analysis of Change in Composition: Benthos, Coral, and Fish Species}

Species composition showed a marked differentiation among the study sites considered. This variation was significant for benthic coverage, as well as in coral and fish species. Similarly, the variation in species composition over time was significant in benthic groups, corals, and fish species. The difference in species composition is greater only between zones or only between dates. Within each site between dates there was not statistically significant (Table 4 and Figure 2).

For benthic coverage composition, all components of the benthos were identified as important contributors between zones, being the abiotic substrate the only coverage value that was not significant. Outplanting sites ZT2 and ZT3 are very similar, while site ZT1 shows stronger differentiation, especially

TABLE 3 | Annual productivity and survival of Acropora cervicornis fragments in the three outplanted sites.

\begin{tabular}{lccc}
\hline & ZT1 & ZT2 & ZT3 \\
\hline Annual productivity & 4.9 & 3.6 & 2.1 \\
Survival (\%) & 83 & 61 & 57.5
\end{tabular}

TABLE 4 | Variation in species composition between dates, zones and between dates and zones.

\begin{tabular}{lccc}
\hline & $\begin{array}{c}\text { Benthos cover } \\
\text { GLM }=\mathbf{1 4 . 6 7} \\
\boldsymbol{p} \text {-value }=\mathbf{0 . 0 0 1}\end{array}$ & $\begin{array}{c}\text { Coral species } \\
\text { GLM }=\mathbf{2 1 . 4 2} \\
\boldsymbol{p} \text {-value }=\mathbf{0 . 0 0 1}\end{array}$ & $\begin{array}{c}\text { Fish species } \\
\mathbf{G L M}=\mathbf{2 4 . 4 1} \\
\boldsymbol{p} \text {-value }=\mathbf{0 . 0 0 1}\end{array}$ \\
\hline Zone & $161.06(0.001,92)$ & $472.3(0.001,92)$ & $381.6(0.001,60)$ \\
Date & $38.40(0.001,91)$ & $109.5(0.001,91)$ & $61.0(0.001,59)$ \\
Zone: date & $37.74(0.049,88)$ & $51.7(0.081,88)$ & $67.2(0.062,56)$
\end{tabular}



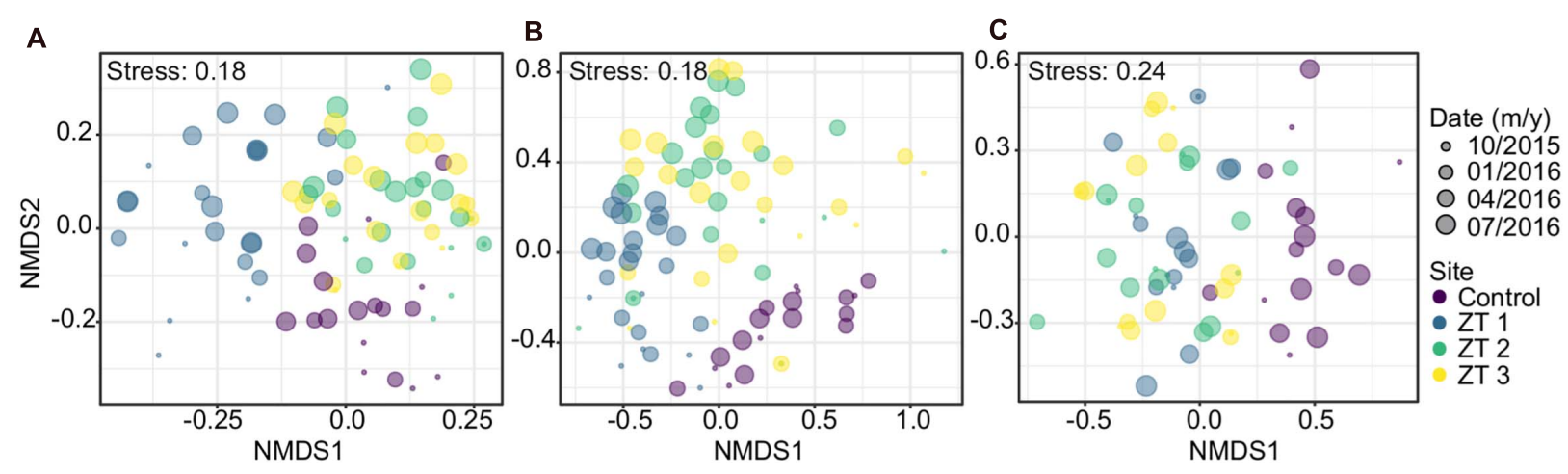

FIGURE 2 | Non-metric multidimensional scaling (NMDS) analysis based on groups' composition: (A) benthos, (B) corals, and (C) fishes in the three outplanted sites and the control site over time.

at earlier dates. Throughout time, outplant sites tended to be increasingly similar in their composition (Figure 2). Change in benthic cover composition over time was mainly attributed to increase coral cover, decrease macroalgae, and abiotic substrate in outplanted areas, these types of cover being significant in the temporal change.

Moreover, 13 of the 29 registered coral species were found to contributed significantly to the variation between areas. The most noticeable result in the case of the temporal variation in the composition of coral species, those that presented significant values, were the species $A$. cervicornis and those belonging to the genus Agaricia spp., observing a general increase of the former (because of the outplanting) and a decrease of the latter (Supplementary Table 2).

Regarding differentiation in fish species composition between zones, six of the 41 species registered was significant (Supplementary Table 3). In fish species the only significant temporal variation was the species $S$. iseri, which presented a considerable increase especially in the outplanted sites.

\section{Ecological Benefits Due to Outplanting}

Analysis of the regression models showed clear ecological benefits due to transplantation, mainly expressed in increased coral cover and increased structural complexity evidenced in the RFI (Figures 3A,B). If we consider date as a descriptive variable in the linear models (Figures 3C,D), the fitting $\left(\mathrm{R}^{2}\right)$ is very low and not significant (Table 5). However, this increase in habitat complexity and coral cover also reflected in an increase in total biomass for all fish species sampled, especially S. iseri (Figures 3E-H).

Coral coverage showed an annual increase of $24.69 \% \pm 5.40 \%$ $\mathrm{SE}$ in the outplanted sites. This increase in coral cover was directly reflected in an increase in RFI, showing an increase of 0.141 RFI, \pm 0.03 SE per year (RFI theoretically ranges from a scale of 0 to $\sim 1$ ), mainly due to the contribution of $A$. cervicornis, a species of high functional value (Table 5). In general, it was observed that the ZT1 area presented a lower increase of coral cover, since from the beginning of outplanting events, it was the one that presented the highest values for coral cover (Figures 3A,B).

The relationship between RFI and coral cover with fish biomass showed an exponential increase, expressed from a linear model with a logarithmic transformation of fish biomass (Figures 3E-H and Table 5). The increase of $\sim 20 \%$ of coral cover and 0.15 RFI ( $\sim$ the 1-year increase in transplant effort) is reflected in an increase of $\sim 1,100 \mathrm{~g} / 100 \mathrm{~m}^{2}$ in untransformed values of fish biomass. This increase in biomass was also found in the species $S$. iseri (the only species found to be significantly $\mathrm{P}$ permuted $<0.05$ in the multivariate GLM). The increase in $S$. iseri biomass was also exponential related to the RFI and coral cover increase, showing a slightly better adjustment than the total biomass (Table 5) and an increase of $\sim 200 \mathrm{~g} / 100 \mathrm{~m}^{2}$ in untransformed values of biomass due to an increase of $\sim 20 \%$ of coral cover and 0.15 RFI.

While efforts in the outplanting sites were intensified, RFI increased directly proportional to the increase in percentage of coral coverage. At the same time, the percentage of macroalgae coverage and abiotic substrate available for colonization decreased.

\section{Ecological Costs Due to the 2016 and 2017 Hurricane Season}

During the study period, three hurricanes (Hurricane Matthew, 2016; Irma and Maria, 2017) directly impacted outplanted sites and some reefs in the Southeast region of the Dominican Republic (National Hurricane Center, NOAA). The impacts of these hurricanes were reflected in the outplanted sites, finding change in species composition and a significant loss of coverage of $24 \%$ for the ZT1 outplanted site (the only one in which the benthos following the impact of hurricanes could be quantified), which occurred between September 2016 and February 1, 2017 (Figures 4A,B). This loss of coverage resulted in a decrease of 0.103 RFI. These results show a significant reduction caused by the Hurricane season (Table 6).

Ecological cost due hurricanes on the fish biomass was not so evident, finding a significant decrease of the total biomass of $1,874.1 \mathrm{~g} / 100 \mathrm{~m}^{2}$ only in the ZT1 site ( $p$-value $\left.=0.030\right)$. However, in other outplanted areas, a decrease in biomass was also identified, despite not being statistically significant (Table 6). 

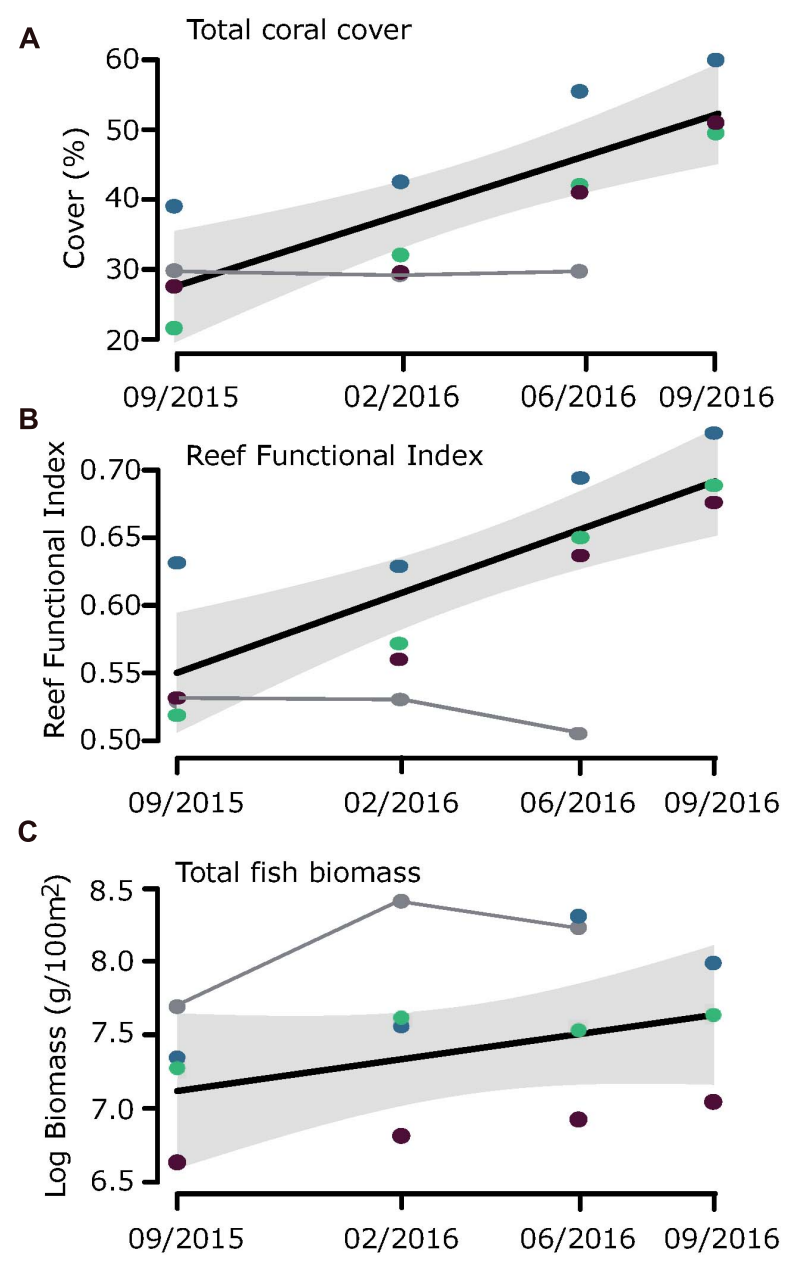

G

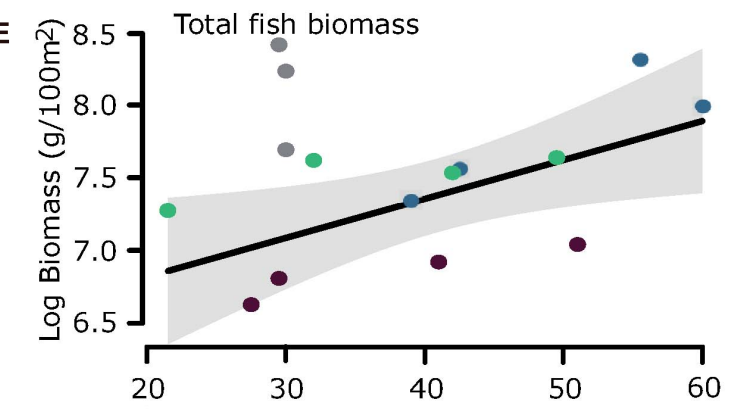

$F$
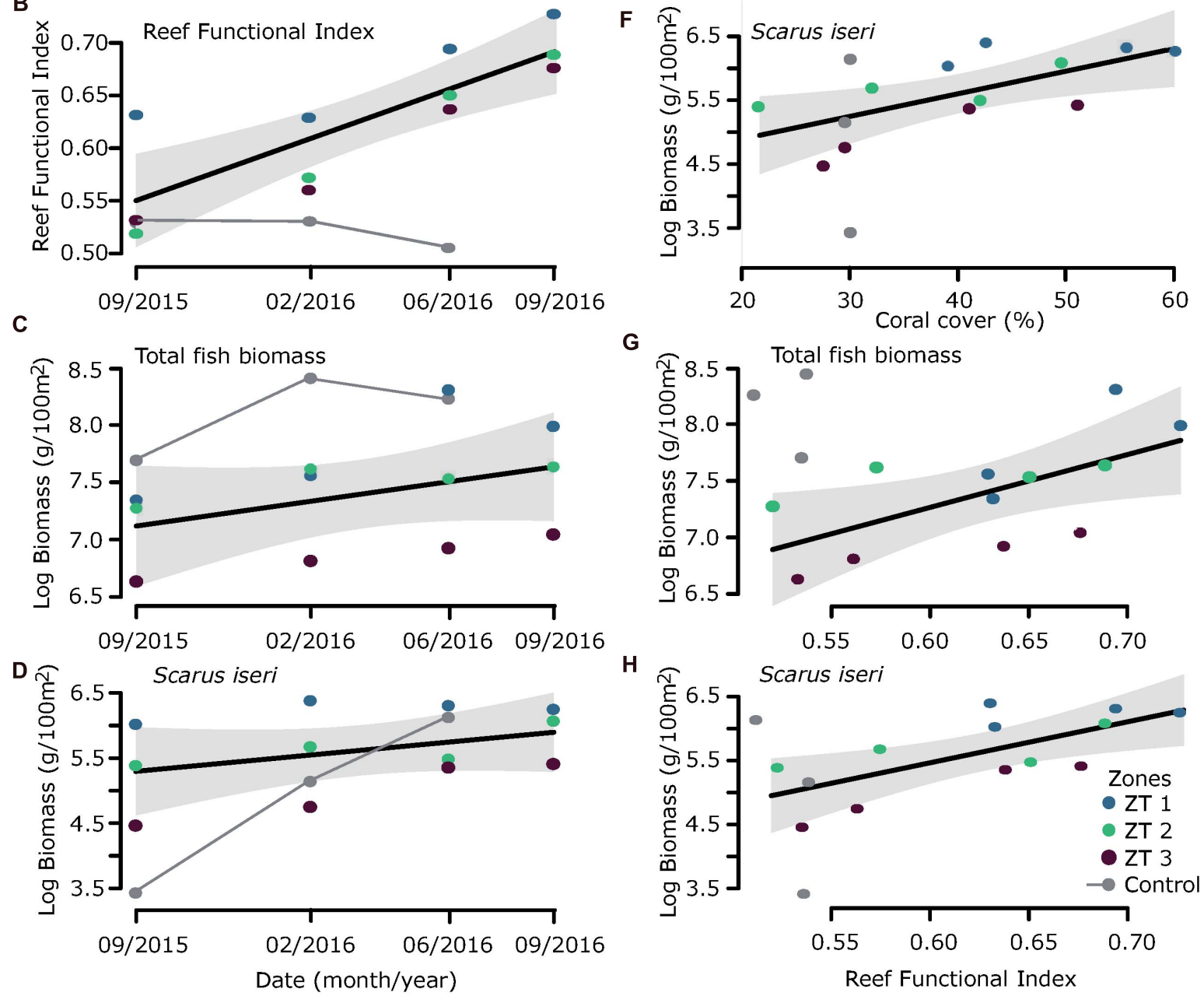

FIGURE 3 | Ecological benefits due to outplanting. Considering date as a descriptive variable (A) coral cover, (B) Reef Functional Index (RFI), (C) total fish biomass, and (D) Scarus iseri biomass. considering Coral cover and RFI as a proxy of habitat complexity, reflected increase in (E,G) total fish biomass and (F,H) Scarus iseri biomass.

\section{DISCUSSION}

To our knowledge, this is the first study to explore the restoration of ecological functions at A. cervicornis outplanted sites in the Dominican Republic by including approaches using multiple variables to describe the correlations between the habitats studied (Bayraktarov et al., 2020; Boström-Einarsson et al., 2020; Seraphim et al., 2020). Here, we demonstrate that active restoration efforts result in direct ecological benefits, and help restore ecological function, expressed in the increased coral cover, structural complexity, and fish biomass described in this study.

To understand the relationship between physical structure features and associated fauna, we monitored progression of two habitat descriptors, both structural, over 12 months, and their association with variation in fish abundance, to identify the role 
TABLE 5 | Linear models of the different variables used during 12-months period of study.

\begin{tabular}{lcccl}
\hline Linear model & DF & $\boldsymbol{F}$-statistic & $\boldsymbol{R}^{\mathbf{2}}$ & $\boldsymbol{p}$-value \\
\hline Coral cover $\sim$ Date & 10 & 20.89 & 0.6763 & 0.001025 \\
RFI $\sim$ Date & 10 & 22.07 & 0.6882 & 0.0008446 \\
Biomass $\sim$ Date & 10 & 2.077 & 0.172 & 0.1801 \\
Scarus iseri $\sim$ Date & 10 & 1.697 & 0.1451 & 0.2219 \\
Biomass $\sim$ Coral cover & 10 & 7.139 & 0.4165 & 0.02342 \\
Scarus iseri $\sim$ Coral cover & 10 & 8.477 & 0.4588 & 0.01552 \\
Biomass $\sim$ RFI & 10 & & & \\
Scarus iseri $\sim$ RFI & 10 & 9.502 & 0.4872 & 0.01159 \\
\hline
\end{tabular}

that Acropora spp. has in maintaining ecosystem services, not only as a creation of breeding habitats for fish (Darling et al., 2017; Floros and Schleyer, 2017), but also by decreasing the space available for colonization by opportunistic fast-growing organisms, such as algae and/or sponges (Agudo-Adriani et al., 2016; Mora et al., 2016). Furthermore, as in this case, the change in the relative cover between A. cervicornis and Agaricia spp. can be beneficial, considering that our results indicate that with restoration efforts, a change in the increased dominance of A. cervicornis is obtained, which would help to recover previous reef states (O'Dea et al., 2020), as efforts in the outplanting sites increase.

Few studies have tracked the community dynamics of reef organisms after restoration (Opel et al., 2017; Bayraktarov et al., 2020; Boström-Einarsson et al., 2020; Seraphim et al., 2020). The results presented in this study show that the positive effects of restoration are reflected in a temporal variation in benthic cover composition, as well as in coral and fish species composition. They show that with the rehabilitation of a single species (A. cervicornis), the functions of an outplanted site, such as herbivory, are recovered by increasing the total biomass of fish and in particular of the parrotfish S. iseri. In this case although this is a small-scale study we were able to observe positive changes over time while active restoration actions were constantly carried out in these reef patches that are part of
TABLE 6 | Ecological cost due hurricanes in three outplanting sites and one control.

\begin{tabular}{|c|c|c|c|c|}
\hline & Zone & $\begin{array}{c}\text { Adjusted mean } \\
\text { difference } \\
\text { (confidence intervals) }\end{array}$ & $p$-value & Size effect \\
\hline Coral cover & ZT1 & $\begin{array}{c}-24(-33.894 \text { to } \\
-14.106)\end{array}$ & $0.005^{\star}$ & 0.91 \\
\hline $\begin{array}{l}\text { Coral functional } \\
\text { coefficient }\end{array}$ & ZT1 & $\begin{array}{c}-0.103(-0.166 \text { to } \\
-0.04)\end{array}$ & $0.0134^{\star}$ & 0.93 \\
\hline \multirow[t]{4}{*}{ Fish biomass } & $\mathrm{ZT1}$ & $\begin{array}{c}-1,874.1(-3,399.1 \text { to } \\
-349.2)\end{array}$ & $0.030^{\star}$ & 0.52 \\
\hline & ZT2 & $\begin{array}{c}-359.8(-3,015.8 \text { to } \\
2,296.2)\end{array}$ & 0.695 & 0.21 \\
\hline & ZT3 & $\begin{array}{c}-293.7(-803.5 \text { to } \\
216.1)\end{array}$ & 0.164 & 0.41 \\
\hline & Control & $\begin{array}{c}-141.1(-2,316.7 \text { to } \\
2,034.6)\end{array}$ & 0.8497 & 0.08 \\
\hline
\end{tabular}

${ }^{*} P<0.05$.

an important MPA for the southeastern zone of the country (Shaver and Silliman, 2017; Calle-Triviño et al., 2018, 2020; Cortés-Useche et al., 2018, 2019, 2021).

Increased $A$. cervicornis coverage may improve the functions of coral reef ecosystems by generating beneficial interactions between species (Shaver and Silliman, 2017), as for example in this case study where it was evident that by performing constant actions of active restoration, such as removal macroalgae when preparing substrate in outplanting sites and by having the surfaces occupied by colonies of $A$. cervicornis, the abiotic substrate available to be colonized also decreased, which may influence the decrease in the cover of opportunistic species such as sponges, algae mats, macro-algae that can contribute to increased bio-erosion (Yap, 2013). In addition, was increasing structural complexity, which was shown to increase RFI and total fish biomass in the outplanted sites.

Improved A. cervicornis cover provides increased structural complexity and architecture of the ecosystem which, in turn provides a greater number of refuges and feeding grounds for other commercially and/or ecologically important invertebrates
A

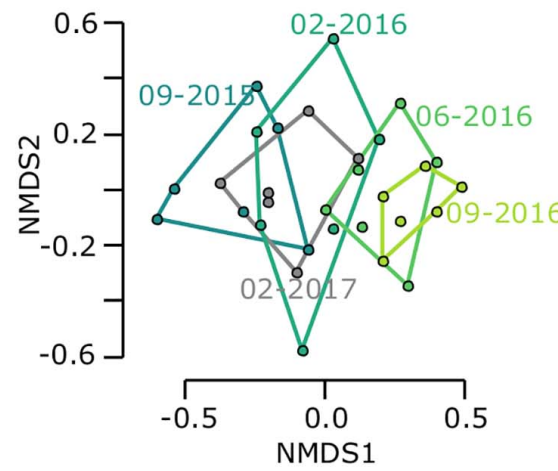

B

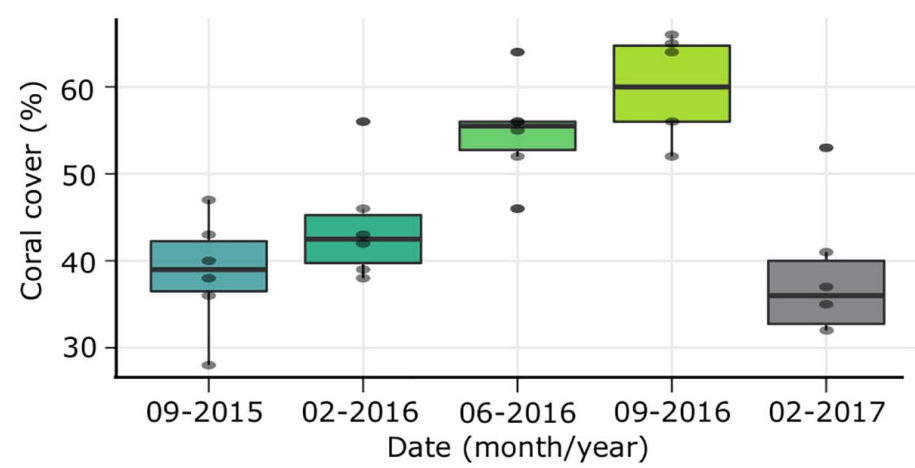

FIGURE 4 | Ecological costs due to Hurricane season 2016-2017. (A) Non-metric multidimensional scaling (NMDS) analysis based on species composition in outplanted site ZT1 over time. (B) Change in coral cover over time. 
(e.g., octopus, lobsters) and of course for reef fish (Cabaitan et al., 2008; Yap, 2009; Schopmeyer and Lirman, 2015; Huntington et al., 2017; Opel et al., 2017; Shaver and Silliman, 2017). Thus, observation of the dynamics of fish communities after transplants is fundamental to understanding the ecology of the system and evaluating the "rapid" contributions of restored sites (Opel et al., 2017; Ladd et al., 2019; Seraphim et al., 2020). Some authors report that outplanting efforts in coral restoration projects cause an immediate change in the ecological function and services of degraded regions of the reef, therefore, they think that restoration influences and in turn facilitates the repair of ecosystem function (AgudoAdriani et al., 2016; Lirman and Schopmeyer, 2016; Opel et al., 2017; Shaver and Silliman, 2017). However, of the more than 200 cases on coral restoration in published scientific literature, whose objectives were primarily aimed at assessing recovery of ecosystem functions, appropriate metrics were not used to assess project success in relation to that objective (Boström-Einarsson et al., 2020).

In the case of fishes, although the temporal variation is significant, it is not as strong as the two components mentioned above (coral cover and structural complexity), in this variation there is a considerable increase in the $S$. iseri species. We therefore suppose that this particular species has a strong association with A. cervicornis. Nevertheless, this is only the first result derived from a small-scale experiment. It is worth mentioning that $S$. iseri is a species that benefits when there is a high connection between habitats, as in the case of mangroves, sea grasses and coral reefs (Mumby et al., 2004; Harborne and Mumby, 2018), these three ecosystems are present in the study area within $<1 \mathrm{~km}$ distance from each other. The presence of these three together may contribute to the recruitment of $S$. iseri. Our results suggest that $A$. cervicornis may be an optimal habitat that can facilitate the reintroduction of $S$. iseri, and it is likely that this fish species is a good indicator of improved fish recruitment conditions as a function of habitat improvement. Considering that this fish is associated with highly complex reefs, it is probable that increasing RFI will be reflected in increased $S$. iseri due to increased habitat availability.

Our results suggest that through active restoration, positive outcomes in reef health are seen. Over short periods of time, this recovery does not equate to sustained recovery of the ecosystem, particularly since events such as El Niño, warming events (which can associate pathogenic microorganisms and disease outbreaks), increased acidification, among others, are becoming more frequent thus reducing recovery time (Hughes et al., 2018; Goergen et al., 2019). The assessment conducted here indicates that after the hurricanes, although there was a decrease in fish biomass, the loss would probably have been greater without restoration efforts (Figure 5). It would be important to observe these analyses when transplanting with other reefbuilding species such as those of the Orbicella complex, which have different functional traits, and to use different indicators that can provide a proxy for the changes that can be observed at the ecosystem level.

These results offer a hopeful glimpse into the return of certain ecosystem functions with sustained reef restoration of A. cervicornis. It will be necessary to monitor the changing ecology of restoration projects long-term to further validate the longevity of these results. While the standard biological metrics of restoration efforts should continue (such as survival and growth of the transplanted corals), this study indicates the functional ecology must also be monitored (Goergen et al., 2020).

This study represents an important advance in the restoration of Caribbean coral reefs, which have been exposed to various impacts that have resulted in significant losses in their coverage, structural complexity and considerable loss of fish biomass (Gardner et al., 2003; Arias-González et al., 2017). Besides, it highlights the importance of restoration and active conservation measures for coral reefs.

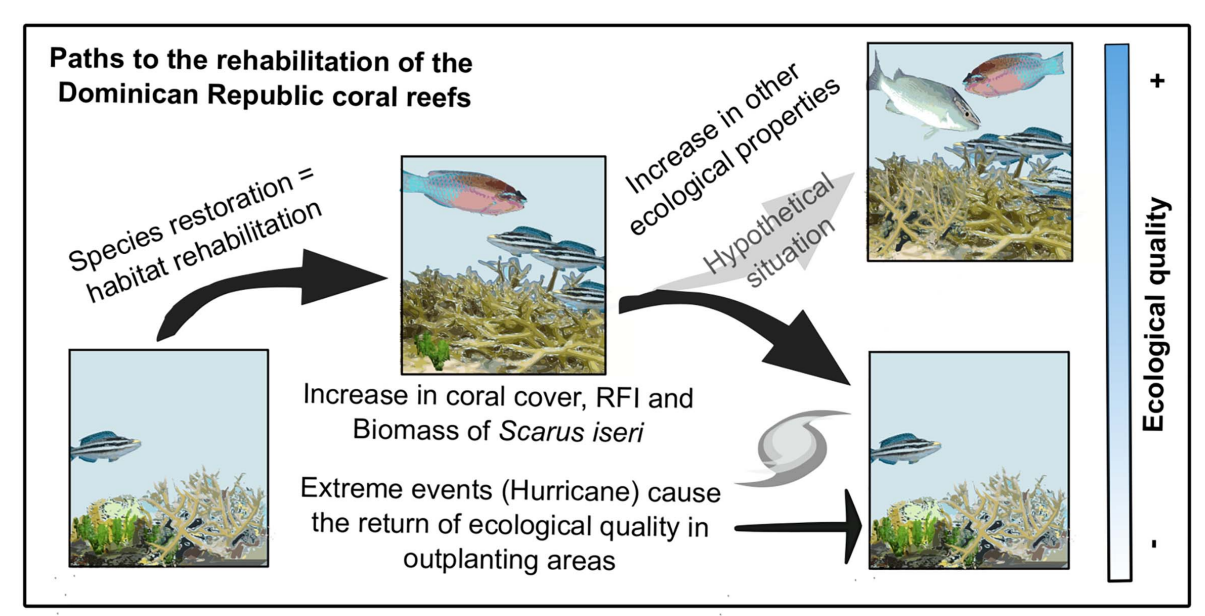

FIGURE 5 | Conceptual model. Species restoration induces habitat rehabilitation, increasing coral cover, RFI, and biomass in this particular case study of Scarus iseri. Damage from storms or hurricanes would be even greater if no active restoration efforts were undertaken. Continued active restoration efforts will improve the ecological health of coral reefs. 
This study emphasizes the relevance of using ecosystemlevel scales of analysis to describe correlations between fish communities and habitat to identify important changes in coral reef function and resilience (Graham and Nash, 2013), and their potential positive effect on coral reef systems. Furthermore, the importance of continuing to increase scientifically based active restoration efforts in the southeast region of the Dominican Republic and to continue to demonstrate the effectiveness of restoration within MPAs.

\section{DATA AVAILABILITY STATEMENT}

The original contributions presented in the study are included in the article/Supplementary Material, further inquiries can be directed to the corresponding author/s.

\section{ETHICS STATEMENT}

The animal study was reviewed and approved by Ministerio de Medio Ambiente y Recursos Naturales de la República Dominicana.

\section{AUTHOR CONTRIBUTIONS}

JC-T conceived and designed the experiments, performed the experiments, analyzed the data, prepared figures and/or tables, authored or reviewed drafts of the manuscript, and approved the final draft. AM-C analyzed the data, prepared figures and/or tables, authored or reviewed drafts of the paper, and approved the final draft. CC-U performed the experiments, analyzed the data, authored or reviewed drafts of the paper, and approved the final draft. MM prepared figures and/or

\section{REFERENCES}

Agudo-Adriani, E. A., Cappelletto, J., Cavada-Blanco, F., and Croquer, A. (2016). Colony geometry and structural complexity of the endangered species Acropora cervicornis partly explains the structure of their associated fish assemblage. PeerJ 4:e1861. doi: 10.7717/peerj.1861

Alvarez-Filip, L., Dulvy, N. K., Gill, J. A., Côté, I. M., and Watkinson, A. R. (2009). Flattening of Caribbean coral reefs: region-wide declines in architectural complexity. Proc. R. Soc. B Biol. Sci. 276, 3019-3025. doi: 10.1098/rspb.2009. 0339

Anthony, K. R. N., Marshall, P. A., Abdulla, A., Beeden, R., Bergh, C., Black, R., et al. (2015). Operationalizing resilience for adaptive coral reef management under global environmental change. Glob. Change Biol. 21, 48-61. doi: 10.1111/ gcb. 12700

Arias-González, J. E., Calle-Triviño, J., Cortés-Useche, C., Cabrera-Pérez, J. L., Muniz-Castillo, A. I., Cabrera-Martínez, J. P., et al. (2015). Restauración y Manejo de sitios arrecifales impactados por fenómenos naturales y antrópicos. Yucatán: CINVESTAV.

Arias-González, J. E., Fung, T., Seymour, R. M., Garza-Pérez, J. R., AcostaGonzález, G., and Bozec, Y. M. (2017). A coral-algal phase shift in Mesoamerica not driven by changes in herbivorous fish abundance. PLoS One 12:e174855. doi: 10.1371/journal.pone.0174855

Aronson, R. B., Bruckner, A., Moore, J., Precht, B., and Weil, E. (2008). IUCN Red List of Threatened Species: Acropora cervicornis. Version 2011.2. Cambridge, MA: International Union for Conservation of Nature and Natural Resources. tables, authored or reviewed drafts of the paper, and approved the final draft. RS-B performed the experiments and approved the final draft. JA-G conceived and designed the experiments, analyzed the data, prepared figures and/or tables, authored or reviewed drafts of the paper, and approved the final draft. All authors contributed to the article and approved the submitted version.

\section{FUNDING}

JC-T, CC-U, and AM-C were supported by mixed program grants provided by CONACyT $(404308,290936$, and 340074).

\section{ACKNOWLEDGMENTS}

We would like to thank the Centro de Investigación y de Estudios Avanzados del Instituto Politécnico Nacional (National Polytechnical Institute Research and Advanced Studies Center, CINVESTAV), FUNDEMAR's technical team for their field assistance, as well as for their material and logistical support, Victor Galván for his support with the english edition of this document; and the Iberostar Group for covering the open access publication fees of this manuscript. We would also like to thank the reviewers for their insightful suggestions for improving the article.

\section{SUPPLEMENTARY MATERIAL}

The Supplementary Material for this article can be found online at: https://www.frontiersin.org/articles/10.3389/fmars. 2021.668325/full\#supplementary-material

Bayraktarov, E., Banaszak, A. T., Montoya-Maya, P., Kleypas, J., Arias-Gonzaález, J. E., Blanco, M., et al. (2020). Coral reef restoration efforts in Latin American countries and territories. PLoS One 15:e0228477. doi: 10.1371/journal.pone. 0228477

Bonsack, J. A., and Harper, D. E. (1988). Length-Weight Relationships of Selected Marine Reef Fishes from the Southeastern United States and the Caribbean. Miami, FL: NOAA. NOAA Tech Memo NMFS-SEFC: 215.

Boström-Einarsson, L., Babcock, R. C., Bayraktarov, E., Ceccarelli, D., Cook, N., Ferse, S. C. A., et al. (2020). Coral restoration - A systematic review of current methods, successes, failures and future directions. PLoS One 15:e0226631. doi: 10.1371/journal.pone.0226631

Bowden-Kerby, A. (2001). Low-tech coral reef restoration methods modeled after natural fragmentation processes. Bull. Mar. Sci. 69, 915-931.

Breheny, P., and Burchett, W. (2017). Visualizing regression models using visreg. RJ. 9, 56-71. doi: 10.32614/rj-2017-046

Bruckner, A. W. (2002). Proceedings of the Caribbean Acropora Workshop: Potential Application of the US Endangered Species Act as a Conservation Strategy. NOAA Tech Memo NMFSOPR-24. Silver Spring, MD: NOAA.

Cabaitan, P. C., Gome, E. D., and Aliño, P. M. (2008). Effects of coral transplantation and giant clam restocking on the structure of fish communities on degraded patch reefs. J. Exp. Mar. Biol. Ecol. 357, 85-98. doi: 10.1016/j.jembe. 2008.01.001

Calle-Triviño, J., Cortés-Useche, C., Sellares, R., and Arias-González, J. E. (2017). First record of the fireworm Hermodice carunculata preying on colonies of the threatened staghorn coral Acropora cervicornis in the southeastern outplanting 
sites of the Dominican Republic. Novitates Caribaea 11, 97-98. doi: 10.33800/ nc.v0i11.17

Calle-Triviño, J., Cortés-Useche, C., Sellares, R., and Arias-González, J. E. (2018). Assisted fertilization of threatened staghorn coral to complement the restoration of nurseries in Southeastern Dominican Republic. Region. Stud. Mar. Sci. J. 18, 129-134. doi: 10.1016/j.rsma.2018.02.002

Calle-Triviño, J., Rivera-Madrid, R., León-Pech, M. G., Cortés-Useche, C., SellaresBlasco, R. I., Aguilar-Espinosa, M., et al. (2020). Assessing and genotyping threatened staghorn coral Acropora cervicornis nurseries during restoration in southeast Dominican Republic. PeerJ 8:e8863. doi: 10.7717/peerj.8863

Carne, L., Kaufman, L., and Scavo, K. (2016). "Measuring success for Caribbean acroporid restoration: key results from ten years of work in southern Belize (abstract no. 27909)," in Proceedings of the 13th International Coral Reef Symposium, Honolulu.

Carpenter, K. E., Abrar, M., Aeby, G., Aronson, R. B., Banks, S., Bruckner, A., et al. (2008). One-third of reef-building corals face elevated extinction risk from climate change and local impacts. Science 321, 560-563. doi: 10.1126/science. 1159196

Chamberland, V. F., Snowden, S., Marhaver, K. L., Petersen, D., and Vermeij, M. J. A. (2015). Restoration of critically endangered elkhorn coral (Acropora palmata) populations using larvae reared from wild-caught gametes. Glob. Ecol. Conserv. 4, 526-537. doi: 10.1016/j.gecco.2015.10.005

Cortés-Useche, C., Calle-Triviño, J., Sellares-Blasco, R., Luis-Báez, A., and AriasGonzález, J. E. (2018). An updated checklist of the reef fishes of the Southeastern Reefs Marine Sanctuary of the Dominican Republic. Rev. Mexic. Biodivers. 89, 382-392.

Cortés-Useche, C., Hernández-Delgado, E. A., Calle-Triviño, J., Sellares-Blasco, R., Galván, V., and Arias-González, J. E. (2021). Conservation actions and ecological context: optimizing coral reef local management in the Dominican Republic. PeerJ [Epub ahead of print].

Cortés-Useche, C., Muñiz-Castillo, A. I., Calle-Triviño, J., Yathiraj, R., and AriasGonzález, J. E. (2019). Reef condition and protection of coral diversity and evolutionary history in the marine protected areas of Southeastern Dominican Republic. Region. Stud. Mar. Sci. 32:100893. doi: 10.1016/j.rsma.2019.100893

D’agata, D., Mouillot, I., Kulbicki, M., Andrefouet, S., Bellwood, D. R., Cinner, J. E., et al. (2014). Human-mediated loss of phylogenetic and functional diversity in coral reef fishes. Curr. Biol. 24, 555-560. doi: 10.1016/j.cub.2014.01.049

Darling, E. S., Graham, N. A. J., Januchowski-Hartley, F. A., Nash, K. L., Pratchett, M. S., and Wilson, S. K. (2017). Relationships between structural complexity, coral traits, and reef fish assemblages. Coral Reefs 36, 561-575. doi: 10.1007/ s00338-017-1539-z

Edwards, A. (2010). Reef Rehabilitation Manual. St Lucia: Coral Reef Targeted Research and Capacity Building For Management.

Edwards, A., and Gómez, E. (2007). Reef Restoration: Concepts \& Guidelines. St. Lucia: CoralReef Targeted Research \& Capacity Building for Management Programme, 4-38.

Ferrari, R., Malcolm, H. A., Byrne, M., Friedman, A., Williams, S. B., Schultz, A., et al. (2018). Habitat structural complexity metrics improve predictions of fish abundance and distribution. Ecography 41, 1077-1091. doi: 10.1111/ecog.02580

Floros, C., and Schleyer, M. H. (2017). The functional importance of Acropora austera as nursery areas for juvenile reef fish on South African coral reefs. Coral Reefs 36, 139-149.

Froese, R., and Pauly, D. (2019). FishBase. Available online at: http://www.fishbase. org (accessed January 13, 2020 ).

Gardner, T. A., Im, C. T., Gill, J. A., Grant, A., and Watkinson, A. R. (2003). Long-term region-wide declines in Caribbean corals. Science 301, 958-960. doi: $10.1126 /$ science. 1086050

Gladfelter, W. B. (1982). White-band disease in Acropora palmata: implications for the structure and growth of shallow reefs. Bull. Mar. Sci. 32, 639-643.

Goergen, E. A., Moulding, A. L., Walker, B. K., and Gilliam, D. S. (2019). Identifying causes of temporal changes in acropora cervicornis populations and the potential for recovery. Front. Mar. Sci. 6:36. doi: 10.3389/fmars.2019.00036

Goergen, E. A., Schopmeyer, S., Moulding, A. L., Moura, A., Kramer, P., and Viehman, T. S. (2020). Coral Reef Restoration Monitoring Guide: Methods to Evaluate Restoration Success from Local to Ecosystem Scales. NOAA Technical Memorandum NOS NCCOS 279. Silver Spring, MD: NOAA.

González-Barrios, F. J., and Álvarez-Filip, L. (2018). A framework for measuring coral species-specific contribution to reef functioning in the Caribbean. Ecol. Indic. 95, 877-886. doi: 10.1016/j.ecolind.2018 .08 .038

Graham, N. A. J., and Nash, K. L. (2013). The importance of structural complexity in coral reef ecosystems. Coral Reefs 32, 315-326. doi: 10.1007/s00338-0120984-y

Griffin, S., Spathias, H., Moore, T. D., Baums, I., and Griffin, B. A. (2012). "Scaling up Acropora nurseries in the Caribbean and improving techniques," in Proceedings of the 12th international Coral Reef symposium, London.

Harborne, A., and Mumby, P. (2018). "FAQs about caribbean parrotfish management and their role in reef resilience," in Biology of Parrotfishes, eds A. S. Hoey and R. M. Bonaldo (Boca Raton, FL: CRC Press).

Hernández-Delgado, E. A., Rosado-Matías, B. J., and Sabbat, A. M. (2001). "Restauración del habitat esencial de peces juveniles mediante la replantación de corales fragmentados en la Reserva Pesquera Marina del Canal de Luis Pen pa, Culebra," in Proceedings of the Memorias del XXIV Simposio de Restauración Natural, Ft. Lauderdale, FL, 98-123.

Hughes, T. P., Anderson, K. D., Connolly, S. R., Heron, S. F., Kerry, J. T., Lough, J. M., et al. (2018). Spatial and temporal patterns of mass bleaching of corals in the Anthropocene. Science 359, 80-83. doi: 10.1126/science.aan8048

Hughes, T. P., Barnes, M. L., Bellwood, D. R., Cinner, J. E., Cumming, G. S., Jackson, J. B. C., et al. (2017). Coral reefs in the Anthropocene. Nature 546, 82-90. doi: 10.1038/nature2290

Huntington, B., Miller, M., Pauch, R., and Ritcher, L. (2017). Facilitation in Caribbean coral reefs: high densities of staghorn coral foster greater coral condition and reef fish composition. Oceologia 184, 247-257. doi: 10.1007/ s00442-017-3859-7

Itzkowitz, M. (1978). Group organization of a territorial damselfish Eupomacentrus planifrons. Behaviour 65, 125-137. doi: 10.1163/156853978x00233

Johnson, M. E., Lustic, C., Bartels, E. I, Baums, B., Gilliam, D. S., Larson, L., et al. (2011). Caribbean Acropora Restoration Guide: Best Practices for Propagation and Population Enhancement. Arlington, VA: The Nature Conservancy.

Knowlton, N. (1992). Thresholds and multiple stable states in coral reef community dynamics. Am. Zool. 32, 674-682. doi: 10.1093/icb/32.6.674

Ladd, M. C., Burkepile, D. E., and Shantz, A. A. (2019). Near-term impacts of coral restoration on target species, coral reef community structure, and ecological processes. Restoration Ecol. 27, 1166-1177. doi: 10.1111/rec.12939

Ladd, M. C., Miller, M. W., Hunt, J. H., Sharp, W. C., and Burkepile, D. E. (2018). Harnessing ecological processes to facilitate coral restoration. Front. Ecol. Environ. 16, 239-247. doi: 10.1002/fee.1792

Lamb, J. B., Willis, B. L., Fiorenza, E. A., Couch, C. S., Howard, R., Rader, D. N., et al. (2018). Plastic waste associated with disease on coral reefs. Science 359, 460-462. doi: 10.1126/science.aar3320

Lang, J. C., Marks, K., Kramer, W., Richards-Kramer, P. A., and Ginsburg, R. N. (2010). AGRRA Protocols Version 5.4.

Lirman, D. (1999). Reef fish communities associated with Acropora palmata: relationships to benthic attributes. Bull. Mar. Sci. 65, 235-252.

Lirman, D., and Schopmeyer, S. (2016). Ecological solutions to reef degradation: optimizing coral reef restoration in the Caribbean and Western Atlantic. PeerJ 4:e2597. doi: 10.7717/peerj.2597

Lirman, D., Schopmeyer, S., Galvan, V., Drury, C., Baker, A. C., and Baums, I. (2014). Growth dynamics of the threatened caribbean staghorn coral acropora cervicornis: influence of host genotype, symbiont identity, colony size, and environmental setting. PLoS One 9:e107253. doi: 10.1371/journal.pone. 0107253

Mair, P., Schoenbrodt, F., and Wilcox, R. (2016). WRS2: Wilcox robust estimation and testing. $R$ package version $0.9-1$.

Mercado-Molina, A., Hernández-Delgado, E. A., Rivera-Rivera, J. E., RiveraRivera, M., Suleimán-Ramos, S. E., Olivo-Maldonado, I., et al. (2013). Protocolo para la propagación y la restauración de poblaciones del coral Cuerno de ciervo, Acropora cervicornis: Estrategias de bajo costo de la Sociedad Ambiente Marino. San Juan, PR: NOAA-Restoration Center \& The Nature Conservancy.

Miller, M. W., Bourque, A. S., and Bohnsack, J. A. (2002). An analysis of the loss of acroporid corals at Looe Key, Florida, USA: 1983-2000. Coral Reefs 21, 179-182. doi: 10.1007/s00338-002-0228-7

Mora, C., Graham, N. A. J., and Nyström, M. (2016). Ecological limitations to the resilience of coral reefs. Coral Reefs 35, 1271-1280. doi: 10.1007/s00338-0161479-z 
Mumby, P. J., Edwards, A. J., Arias-González, J. E., Lindeman, K. C., Blackwell, P. G., Gall, A., et al. (2004). Mangroves enhance the biomass of coral reef fish communities in the Caribbean. Nature 427, 533-536. doi: 10.1038/nature02286

Nakamura, K., Gaines, K., and Roach, S. (2011). Coral tree nursery: an innovative approach to growing corals in an ocean-based field nursery. AACL Bioflux 4, $442-446$.

O’Dea, A., Lepore, M., Altieri, A. H., Chan, M., Morales-Saldaña, J. M., Muñoz, N., et al. (2020). Defining variation in pre-human ecosystems can guide conservation: an example from a Caribbean coral reef. Sci. Rep. 10: 2922. doi: 10.1038/s41598-020-59436-y

Opel, A. H., Cavanaugh, C. M., Rotjan, R. D., and Nelson, J. P. (2017). The effect of coral restoration on Caribbean reef fish communities. Mar. Biol. 164:221. doi: 10.1007/s00227-017-3248-0

Pena, E. A., and Slate, E. H. (2006). Global validation of linear model assumptions. J. Amer. Statist. Assoc. 101, 341-354. doi: 10.1198/016214505000000637

Pendleton, L. H., Hoegh-Guldberg, O., Langdon, C., and Comte, A. (2016). Multiple stressors and ecological complexity require a new approach to coral reef research. Front. Mar. Sci. 3:36. doi: 10.3389/fmars.2016.00036

Petersen, D., Laterveer, M., and Visser, G. (2007). Sexual Recruitment of the Corals Favia fragum and Agaricia humilis in a $30 \mathrm{~m} 3$ exhibit aquarium: species- Specific limitations and implications on reproductive ecology. Zool. Biol. 26, 75-91. doi: 10.1002/zoo. 20120

Porter, J. W., Battey, J., and Smith, G. (1982). Perturbation and change in coral reef communities. Proc. Natl. Acad. Sci. U.S.A. 79, 1678-1681. doi: 10.1073/pnas.79. 5.1678

Precht, W. (2006). Coral Reef Restoration Handbook. Boca Raton, FL: Taylor and Francis.

Precht, W., Bruckner, A., Aronson, R., and Bruckner, R. J. (2002). Endangered acroporid coral of the Caribbean. Coral Reefs 21, 41-42. doi: 10.1007/s00338001-0209-2

R Development Core Team (2015). R: A Language and Environment for Statistical Computing. Vienna: R Foundation for Statistical Computing.

Rinkevich, B. (2005). Conservation of coral reefs through active restoration measures: recent approaches and last decade progress. Environ. Sci. Tech. 39, 4333-4342. doi: 10.1021/es0482583

Rinkevich, B. (2015). Climate change and active reef restoration -ways of constructing the "reefs of tomorrow". J. Mar. Sci. Eng. 3, 111-127. doi: 10.3390/ jmse3010111

Schopmeyer, S. A., and Lirman, D. (2015). Occupation dynamics and impacts of damselfish territoriality on recovering populations of the threatened staghorn coral, Acropora cervicornis. PLoS One 10:e0141302. doi: 10.1371/journal.pone. 0141302

Schopmeyer, S. A., Lirman, D., Bertels, E., Gilliem, D. S., Goergen, E. A., Griffin, S. P., et al. (2017). Regional restoration benchmarks for Acropora cervicornis. Coral Reefs 36, 1047-1057. doi: 10.1007/s00338-0171596-3

Seraphim, M., Sloman, K., Alexander, M., Janetski, N., Jompa, J., Ambo-Rappe, R., et al. (2020). Interactions between coral restoration and fish assemblages: implications for reef management. J. Fish Biol. 97, 633-655. doi: 10.1111/jfb. 14440

Shaver, E. C., Courtney, C. A., West, J. M., Maynard, J., Hein, M., Wagner, C., et al. (2020). A Manager's Guide to Coral Reef Restoration Planning and Design. Silver Spring, MD: NOAA.

Shaver, E. C., and Silliman, B. R. (2017). Time to cash in on positive interactions for coral restoration. PeerJ 5:e3499. doi: 10.7717/peerj. 3499

Toh, T. C., Guest, J., and Chou, L. (2012). Coral larval rearing in Singapore: observations on spawning timing, larval development and settlement of two common scleractinian coral species. Contrib. Ti Mar. Sci. 5, 81-87.

Vargas-Ángel, B., Colley, S. B., Hoke, S. M., and Thomas, J. D. (2006). The reproductive seasonality and gametogenic cycle of Acropora cervicornis off Broward County, Florida, USA. Coral Reefs 25, 110-122. doi: 10.1007/s00338005-0070-9

Warton, D. I., Blanchet, F. G., O'Hara, R. B., Ovaskainen, O., Taskinen, S., Walker, S. C., et al. (2015). So many variables: joint modeling in community ecology. Trends Ecol. Evol. 30, 766-779. doi: 10.1016/j.tree.2015.09.007

Warton, D. I., Wright, S. T., and Wang, Y. (2012). Distance-based multivariate analyses confound location and dispersion effects. Methods Ecol. Evol. 3, 89101. doi: 10.1111/j.2041-210x.2011.00127.x

Weil, E., Hernandez-Delgado, E. A., Bruckner, A., Ortiz, A., Nemeth, M., and Ruiz, H. (2002). "Distribution and status of acroporid populations in Puerto Rico," in Proceedings of the Caribbean Acropora Workshop 'Potential Application of the US Endangered Species Act as a Conservation Strategy', ed. A. W. Bruckner (Silver Spring, MD: NOAA).

Yap, H. T. (2009). Local changes in community diversity following coral transplantation. Mar. Ecol. Progr. Ser. 374, 33-41. doi: 10.3354/meps07650

Yap, H. T. (2013). “Coral reef ecosystems," in Earth System Monitoring, ed. J. Orcutt (New York, NY: Springer).

Young, C., Schopmeyer, S., and Lirman, D. (2012). A review of reef restoration and coral propagation using the threatened genus Acropora in the Caribbean and western Atlantic. Bull. Mar. Sci. 88, 1075-1098. doi: 10.5343/bms.2011.1143

Conflict of Interest: JC-T, CC-U, and MM are the employees of the Wave of Change Iberostar Hotels and Resorts.

The remaining authors declare that the research was conducted in the absence of any commercial or financial relationships that could be construed as a potential conflict of interest.

Copyright (C) 2021 Calle-Triviño, Muñiz-Castillo, Cortés-Useche, Morikawa, SellaresBlasco and Arias-González. This is an open-access article distributed under the terms of the Creative Commons Attribution License (CC BY). The use, distribution or reproduction in other forums is permitted, provided the original author(s) and the copyright owner(s) are credited and that the original publication in this journal is cited, in accordance with accepted academic practice. No use, distribution or reproduction is permitted which does not comply with these terms. 